\title{
When it Comes to Contact Disputes, What are Family Courts For?
}

Felicity Kaganas*

\section{Introduction}

The easy answer to the question 'What are family courts for?' is of course, in the traditional civil adversarial system, to make decisions and to resolve disputes. But the answer has not been straightforward in child and family disputes, and recently it has become even less clear cut. This article is intended to examine how the role of the family court has been changing in the context of contact disputes, why it has changed and what the implications of the latest developments might be. It will suggest that there is now a blurring of the roles of adjudication and social work intervention and consider what this might lead to.

\section{The Challenges}

The problems faced by the Family Courts in disputes about children have increased in number and in complexity over the years. And the demands made on the courts by policy-makers, the legislature and the public have grown as new problems have presented themselves.

In the nineteenth and early twentieth centuries, no-one questioned the need for divorce courts to make decisions about children and the power was not contentious. The decisions were amenable to judicial determination because they involved the use of rules of thumb (such as the mother's adultery), or common sense. ${ }^{1}$ Indeed decisions about children were subsidiary to the question of whether the divorce would be granted. ${ }^{2}$

\footnotetext{
* My thanks to Christine Piper and Alison Diduck for their comments on earlier drafts.

${ }^{1}$ Once the problem became defined as 'psychological' there were calls for abandonment of these rues of thumb (J. Brophy, 'Child Care and the Growth of Power: The Status of Mothers
} 
After World War II, the welfare of the child came to occupy centre stage in relation to disputes after divorce and a need for courts to be informed about welfare issues was identified. $^{3}$ The Finer Committee, reporting in 1974, recommended that the court should provide facilities for conciliation and have trained staff to assist with matters requiring social work assistance and advice. ${ }^{4}$ The task of the court was clearly becoming more complex.

The powers of the court were revisited during the drafting of the Children Act 1989. This statute was intended to embody a comprehensive code dealing with children and their welfare. In the context of private law, the legislation was intended to address a number of concerns that had preoccupied Government, legal and welfare professionals and the Law Commission ${ }^{5}$ in the 1980s. Chief among these was a perceived need for continuity in order to promote children’s well-being and, more specifically, the need for children to maintain their relationships with both parents. However there was also a growing awareness of the limits of legal action. ${ }^{6}$ Doubts were beginning to surface about the usefulness of court intervention in determining arrangements, and particularly contact arrangements, for children after separation

in Child Custody Disputes' in J. Brophy and C. Smart (eds.), Women in Law: Explorations in Law, Family and Sexuality (London: Routledge and Kegan Hall, 1985) p 106.

${ }^{2}$ S. Cretney, Family Law in the Twentieth Century. A History (Oxford: Oxford University Press, 2003/5) pp 576, 743.

${ }^{3}$ Ibid. p743.

${ }^{4}$ DHSS, Report of the Committee on One-Parent Families, Vol 1 (London: HMSO, 1974), para 4.283.

${ }^{5}$ The Law Commission, Working Paper no 96 Family Law: Review of Child Law: Custody (London: HMSO,1986) esp at para 3.7.

${ }^{6}$ See C. Piper, The Responsible Parent. A Study in Divorce Mediation (London: Harvester Wheatsheaf, 1993), p 9. 
or divorce. ${ }^{7}$ There were concerns about the effects of parental conflict on children and the role of the court process in exacerbating this. Litigation was coming to be regarded as not only costly but also as counter-productive. There were, therefore, different problems demanding different solutions.

The solution to the problem of satisfying the perceived need for children to maintain their relationships with both parents after separation or divorce was to prioritize contact with the non-resident parent. Courts had already begun to attach greater importance to contact in the 1970s and by the 1990s there had developed a strong presumption, now modified in Re $\mathrm{L}^{8}$ to become an 'assumption', in favour of contact. In Re L, for example, the court referred with approval to an earlier case, Re $\mathrm{O},{ }^{9}$ where it was said that it is 'almost always' in the child's best interests to have contact.

The main response to the concerns about cost, conflict and the deficiencies of the court as the forum for decision-making was to seek to change the way disputes were dealt with and to have them resolved in a way that avoided the need for court battles. Following from the

\footnotetext{
${ }^{7}$ See B. Hoggett, 'Joint Parenting Systems: The English Experiment', (1994) 6 J of Child Law 8, 9; A. Diduck and F. Kaganas, Family Law, Gender and the State (Oxford: Hart Publishing, 2006), p 281.

${ }^{8}$ Re L (Contact: Domestic Violence); Re V (Contact: Domestic Violence); Re M (Contact: Domestic Violence); Re H (Contact: Domestic Violence) [2000] 2 FLR 334 (CA), 364. ${ }^{9}$ See Re O (Contact: Imposition of Conditions) [1995] 2 FLR 124, 129-30: 'Furthermore, neither parent should be allowed to think that 'the more intransigent,... unreasonable,... obdurate... and.. unco-operative they are, the more likely they are to get their own way.' See also Re P (Children) [2008] EWCA Civ 1431, [2009] 1 FLR 1056 [38]: [C]ontact should not be stopped unless it is the last resort for the judge'.
} 
recommendations of the Finer Committee, alternative dispute resolution came to be seen as the best way of achieving this.

\section{Litigation as a Last Resort}

Disquiet about the role of the courts continues and has been articulated by both policymakers and the judiciary. For instance, the Ministerial Foreword to the Green Paper that preceded the Children and Adoption Act 2006 stated that '[t]he current way in which the courts intervene in disputed contact cases does not work well' ${ }^{10}$ Amongst the judiciary, Wall LJ has been particularly outspoken on the matter and has described the court process as 'stressful..., expensive, slow and adversarial.' 'It tends,' he said, 'to entrench parental attitudes rather than encouraging them to change. It is ill-adapted to dealing with the difficult human dilemmas involved, notably when it comes to the enforcement of its orders'. ${ }^{11}$ Similarly, Lord Justice Thorpe said, in Re L, that the family justice system has only limited capacity 'to produce good outcomes in disputed areas of personal relationship'. ${ }^{12}$

${ }^{10}$ DCA, DfES and DTE, Parental Separation: Children's Needs and Parents' Responsibilities, Cm 6273 (London: The Stationery Office, 2004), p1. See also, The Advisory Board on Family Law: Children Act Sub-Committee, Making Contact Work, A Report to the Lord Chancellor on The Facilitation of Arrangements for Contact Between Children and their Non-residential Parents and the Enforcement of Court Orders for Contact, (London: The Stationery Office, 2002), para 1.10; DCSF, Support for All, Cm 7787 (London: TSO, 2010), p9.

${ }^{11}$ Re O (Contact: Withdrawal of Application) [2003] EWHC 3031 (Fam), [2004] 1 FLR 1258 [6(6)].

${ }^{12}$ Re L (Contact: Domestic Violence) p366 
Because the courts were and are thought to be less than ideal for resolving contact disputes, they have been designated a 'last resort'. ${ }^{13}$ Insofar as the dispute, and more specifically, litigation of the dispute, has been regarded as the problem, agreement has been designated the solution. And insofar as agreement has been seen as evidence of co-operation, it has been seen as the solution to the problems of conflict and re-litigation. Alternative dispute resolution continues to be promoted as the most promising mechanism for achieving agreement.

The now defunct divorce procedure embodied in the Family Law Act 1996 placed ADR at the centre of the divorce process. And although the main provisions of the statute will not come into force, the Labour government always maintained a commitment to promoting mediation and in-court conciliation. ${ }^{14}$ At the time of writing, the coalition government has been in office only a week and what policies will emerge remains to be seen. However, the Centre for Social Justice which, while declaring itself non-partisan, appears to reflect the views of the Conservative end of the political spectrum, recommends 'that ADR should be properly regarded as primary dispute resolution and that there should be primary legislation to make family law arbitration binding in law, ${ }^{15}$

\footnotetext{
${ }^{13}$ See, eg, The Advisory Board on Family Law, Making Contact Work, para 1.9.

${ }^{14}$ See eg See eg DCA, DfES and DTI, Parental Separation: Children's Needs and Parents' Responsibilities: Next Steps Cm 6452 (London, The Stationery Office, 2005) p11; DCSF, Support for All, paras 4.33-4.36

${ }^{15}$ The Family Law Review, Every Family Matters. An In-depth Review of Family Law in Britain. A Policy Report by the Family Law Review (London, The Centre for Family Justice, 2009) Executive Summary 25 (emphasis in original). The Centre is chaired by Iain Duncan Smith.
} 
The emphasis on settlement has permeated the family justice system. Where cases do get to court, the aim of the lawyers, the judge and Cafcass is to get the parties to reach an agreement. Negotiation between solicitors, admonishment from the bench, in-court conciliation and reports by Cafcass are all deployed in the effort to make a final hearing avoidable. ${ }^{16}$ The new Practice Direction issued pursuant to the Revised Private Law Programme continues with this approach and stipulates that a Cafcass Family Court Advisor and where possible a mediator should attend the first hearing. ${ }^{17}$ The court, 'in collaboration with the Cafcass Officer, and with the assistance of any mediator present, will seek to assist the parties in conciliation and in resolution of all or any of the issues between them'. ${ }^{18}$ The possibility of intervention by Cafcass, mediation by an external provider and collaborative law must also be considered. ${ }^{19}$

However, while ADR remains central to family policy and practice, it is no panacea. In its favour, there is evidence that ADR mechanisms are effective in some cases. Trinder and Kellett, for example, found that in-court conciliation seemed to result in contact for 'significantly more’ children and that children were having more contact than they had had previously. ${ }^{20}$ However, their research also revealed two problems. First, agreements reached

\footnotetext{
${ }^{16} \mathrm{~J}$. Hunt and A. Macleod, Outcomes of Applications to Court for Contact Orders after Parental Separation or Divorce (London: Ministry of Justice, 2008), p168ff.

${ }^{17}$ Practice Direction. The Revised Private Law Programme, 26 March 2010, para 4.1.

${ }^{18}$ Ibid. para 4.4. See also para 5.2(a).

${ }^{19}$ Ibid. para 5.2 (c)

${ }^{20}$ L. Trinder and J. Kellett, The Longer Term Outcomes of In-court Conciliation. Ministry of Justice Research Series 15/07 (London: Ministry of Justice, 2007) p 50.
} 
in conciliation broke down; $40 \%$ of cases returned to court within two years. ${ }^{21}$ The second problem was that parents remained in conflict. $^{22}$

This and other research indicates that, that in spite the spread of the settlement culture, the tide of litigation over contact has not been stemmed. ${ }^{23}$ It is true that most cases are settled and that, at about $10 \%$ of contact arrangements, ${ }^{24}$ the proportion of cases that reaches the courts is relatively small. Nevertheless these cases are numerically significant and it is reasonable to assume that these cases are among the most bitterly fought, involving high levels of conflict. ${ }^{25}$ This means that the courts, despite doubts about their suitability or efficacy when it comes to conflict within families, are forced to deal with the most intractable disputes, for it is generally agreed that there is no other forum that can do so. ${ }^{26}$

In executing this task, the courts have predictably been subject to criticism. In the past 10 years or so, they have been criticised on two main fronts. First, women’s groups, domestic violence campaigners and some child welfare organisations have criticised the strong procontact ethos that has dominated both ADR and judicial decision-making. They warned that the issue of domestic violence was not being addressed and that women and children were

${ }^{21}$ Ibid, p 50. Re-litigation rates might have been even higher, they observed, had parents not given up because they did not believe the court would help or because they were unable to bear the financial and emotional cost.

22 Ibid. p 51.

${ }^{23}$ See eg R. Bailey-Harris, G. Davis, J. Barron \& J. Pearce, Monitoring Private Law Applications under the Children Act 1989. Research Report to the Nuffield Foundation (Bristol: University of Bristol, 1998), p 16

${ }^{24}$ See A. Blackwell \& F. Dawe, Non-Resident Parental Contact. Final Report. (London: Office for National Statistics, 2003). See also Hunt and Macleod, Outcomes, p 92.

${ }^{25}$ See Hunt and Macleod, Outcomes, p 3 and references cited there.

${ }^{26}$ See below. 
being left vulnerable to abuse in the rush to promote contact. Secondly, there were, and there continue to be, vociferous complaints from fathers' rights groups claiming that contact agreements and orders are being disobeyed, and are being disobeyed with impunity, by unreasonable mothers. These complaints have been well-publicised by the media. And it has been said that the failure to bring recalcitrant mothers into line must be undermining public confidence in the family justice system.

In order to maintain credibility, the courts have to try to meet the public's expectations of them and be seen to respond. In the light of the opposing pressures that the court system has been facing, it has sought to implement the mantra now repeated in policy documents: contact should be the aim 'as long as it is safe'. ${ }^{27}$ So now, alongside the emphasis on promoting contact and settlement, attention is also being paid to safety by means of measures such as risk assessments, ${ }^{28}$ fact-finding hearings ${ }^{29}$ and judicial scrutiny of consent orders ${ }^{30}$ as well as the use of indirect or supervised contact. ${ }^{31}$ In practice, however, it appears still to be the case that contact is regarded as being almost invariably in children's best interests; unless it can be

\footnotetext{
${ }^{27}$ See e.g. DCA, DfES and DTI, Parental Separation: Children's Needs and Parents' Responsibilities: Next Steps, p5.

${ }^{28}$ Primarily relating to the safety of the child. See e.g. Practice Direction, The Revised Private Law Programme, para 3.9; The President’s Renewed Interim Guidance for England, 1 April 2010 para 16.

${ }^{29}$ See Practice Direction; Residence and Contact Orders: Domestic Violence and Harm, [2009] 1 FCR 223, paras 21-23.

${ }^{30}$ See Practice Direction, The Revised Private Law Programme, paras 1.3, 5.3.

${ }^{31}$ See Practice Direction; Residence and Contact Orders: Domestic Violence and Harm, paras 26-29.
} 
established that the non-resident parent (usually the father) poses a significant risk, ${ }^{32}$ contact will be ordered and, increasingly, enforced.

\section{The Importance of Contact}

The 'good' post-separation family is portrayed as one that eschews conflict and ensures that children's relationships with both parents are preserved. ${ }^{33}$ This vision is embraced by policymakers, legislators, the courts, legal professionals and Cafcass officers. ${ }^{34}$ So entrenched is the conviction that contact is important for children that it appears that the courts treat the absence of contact as presenting the greatest risks to children's well-being resulting from parental separation or divorce. ${ }^{35}$ Except in cases of serious violence or abuse, there appears to be little or no acknowledgement in either political or legal discourse of research that does not support the assumption that contact is "necessarily "good" and that children are damaged if it is not sustained' ${ }^{36}$

${ }^{32}$ See, for example, Re D (Contact: Reasons for Refusal) [1997] 2 FLR 48 (CA); Re M (Contact: Violent Parent) [1999] 2 FLR 321 (FD); Re L (Contact: Domestic Violence); Re F (Contact) [2007] EWHC 2543 (Fam); [2008] 1 FLR 1163. In Re W (Permission to Appeal) ([2007] EWCA Civ 786, [2008] 1 FLR 406), Wall LJ, setting out to refute claims that the family justice system dispenses injustice, identified the problem as being unreasonable and indeed 'bad' fathers rather than the courts. See also Re Bradford; Re O'Connell [2006] EWCA Civ 1199; [2007] 1 FLR 530. Compare, for example, Re J-S (a child) (contact: parental responsibility) [2002] EWCA Civ 1028; [2002] 3 FCR 433.

33 Diduck \& Kaganas, Family Law, Gender and the State, p 316.

${ }^{34}$ It was also endorsed by the Labour government. The new government may well do so even more emphatically. See The Family Law Review Every Family Matters, ch 5 ${ }^{35}$ F. Kaganas 'Contact, Conflict and Risk’ in S. Day Sclater and C. Piper (eds.), Undercurrents of Divorce (Aldershot: Dartmouth Publishing Company Limited, 1999). ${ }^{36}$ Diduck \& Kaganas, Family Law, Gender and the State, p 318. See, for an account of such research findings, J. Pryor and B. Rodgers, Children in Changing Families: Life after 
Why so much importance is attached to contact has been extensively canvassed elsewhere. The explanations have included a combination of the influence of fathers' rights groups which deploy equality arguments; the new right seeking to maintain the semblance of the nuclear family despite parental separation; ${ }^{37}$ and research findings indicating that children benefit from contact. ${ }^{38}$ While the influence of the new right has waned, ${ }^{39}$ equality and welfare arguments retain considerable force. In particular, the authority of child welfare 'science' renders it an unassailable ‘truth' that contact is almost always good for children.

In fact, child welfare knowledge is far more nuanced than policymakers and the legal system allow; the findings relied on tend to be rather more qualified than the way in which they are portrayed and, indeed, research findings of some studies are contradicted by others. That within law and politics contact has come to be seen as almost invariably beneficial despite evidence to the contrary may be explained by the propensity of social systems for selective interpretation and oversimplification of social science and child welfare research. King and

Parental Separation (Oxford: Blackwell, 2001). See also J. Walker, McCarthy, C. Stark and K, Laing, Picking up the Pieces: Marriage and Divorce: Two Years After Information Provision (London: Department of Constitutional Affairs, 2004) p314. See also Kaganas 'Contact, Conflict and Risk', pp107-8 and the studies referred to there.

${ }^{37}$ See C. Smart, 'Power and the Politics of Child Custody' in C. Smart and S. Sevenhuijsen (eds.), Child Custody and the Politics of Gender (London: Routledge, 1989)

${ }^{38}$ See e.g. J. Wallerstein and J. Kelly, Surviving the Breakup: How Children and Parents Cope with Divorce (New York: Basic Books, 1980).

${ }^{39}$ Although the emphasis on marriage and the nuclear family is re-emerging in conservative thinking. See Family Law Review, Every Family Matters. 
Piper $^{40}$ argue that because law ${ }^{41}$ is an autopoetic system, there are difficulties inherent in translating child welfare discourse into legal discourse. They assert that the way the law 'thinks' about children is different from the way that child welfare science does.

Law as a system of communication has nothing to say about what is good or bad for children. For that assessment the law has to look to child welfare knowledge. Yet in order to fulfil its function as a system for making decisions, for making findings about right and wrong, the law has to reconstruct child welfare knowledge in terms that 'make sense' to it. This leads to reductionism as law cannot accommodate the complexities and the uncertainties of the available research. Law reinterprets and simplifies child welfare knowledge and also makes choices from available principles. Rather than choosing the path of abandoning contact where it is fraught and difficult, as was often the case in the past, the law has in more recent years set itself the task of removing the obstacles to contact. ${ }^{42}$ In most cases, it is recalcitrant mothers who are seen as the main obstacles; resident parents (usually mothers) who oppose or frustrate contact are seen as jeopardising their children's well-being. And the legal system has, it seems, redoubled it efforts in response to the lobbying of fathers' rights groups and their ability to give very public expression to their grievances.

\section{Resident Parents and Contact - encouraged, persuaded, pushed or forced?}

\footnotetext{
${ }^{40}$ M. King and C. Piper, How the Law Thinks About Children (Aldershot: Arena, 1995), p50.

41 The same would apply to politics.

42 The change from earlier interpretations of child welfare knowledge is striking. The Law Commission in 1986 acknowledged the contradictions in the available research. However it thought that the security of the child's environment and the security of the resident parent should take priority over the maintenance of beneficial links with the non-resident parent (The Law Commission, Working Paper no 96 Family Law: Review of Child Law:

Custody,(London: HMSO, 1986) para 3.7-3.8; para 4.21)
} 
It appears to have been the complaints of fathers' rights groups that led to the commissioning of a research study by Hunt and Macleod. ${ }^{43}$ This research was undertaken as a result of a commitment by the Labour Government to Parliament to establish an evidence base in the light of anecdotal accounts that fathers were being unfairly treated. ${ }^{44}$ Using a sample of cases initiated in 2004, it set out to examine decision-making in contact cases in the context of 'claims that non-resident parents do not get a fair deal from the family courts in that they may get little or no contact for no good reason'. ${ }^{45}$ The researchers concluded that only a small proportion of non-resident parents (10\%) might be seen as getting a 'poor deal', but that this tended only to relate to quantum of contact. In addition unfairness to a parent did not mean unfairness to the child; often it was the child's objections that led to the decision. ${ }^{46}$ Also, the non-resident parent's refusal to co-operate with the court process was a common reason for the outcome. ${ }^{47}$

Hunt and Macleod found no evidence of court bias against fathers. ${ }^{48}$ On the contrary, they found that 'the court starts from the position that contact is generally regarded as being in the interests of children and unless there are very good reasons to the contrary, is likely to be ordered at the end of the day'. ${ }^{49}$ Often, in cases of maternal resistance, enforcement

\footnotetext{
${ }^{43}$ Hunt \& Macleod, Outcomes.

${ }^{44}$ Ibid. p3.

${ }^{45}$ Ibid. p239.

${ }^{46}$ Ibid. p246

${ }^{47}$ Ibid. p 247

${ }^{48}$ Ibid. p253

${ }^{49}$ Ibid. p251.
} 
proceedings appear to have led to renewed contact and this was attributed by the researchers, in some cases, to threats of a penal notice ${ }^{50}$ or a transfer of residence. ${ }^{51}$

The research reveals that persuasion and coercion appeared to be used even in cases where mothers' refusal to co-operate stemmed from justifiable fears. The authors record that serious welfare concerns, such as substance abuse, mental illness, child abuse and domestic violence were raised in nearly two thirds of the cases analysed. Almost half of all the cases involved allegations of domestic violence and in some instances the resident parent raised multiple welfare issues. ${ }^{52}$ In most of the cases involving allegations of domestic violence, these were admitted, proved or supported by evidence. ${ }^{53}$ Nevertheless $70 \%$ of the cases in the sample ended with a contact order. ${ }^{54}$ Most dispositions were for face to face contact and half of those allowed staying contact. While some applications were withdrawn, in only one case out of 286 was there an order for no contact. ${ }^{55}$ Of the cases where at least one serious welfare concern was raised, $60 \%$ ended with staying or unsupervised visiting contact. ${ }^{56}$ Neither domestic violence ${ }^{57}$ nor the objections of children, especially if young, were necessarily considered an impediment to contact. ${ }^{58}$ The courts were seen to 'bend over backwards to try

\footnotetext{
${ }^{50}$ Although courts were reluctant to impose a penal notice. See Hunt \& Macleod, Outcomes, p138, 195-6.

${ }^{51}$ Hunt \& Macleod Outcomes, p 148ff; p195. Threats might be made by solicitors (p 143), the courts or by Cafcass (p175).

${ }^{52}$ Ibid. p 9.

53 Ibid. p 84.

${ }^{54}$ Ibid. pp $11-12$.

55 Ibid. p13. See also p 55.

${ }^{56}$ Ibid. p16

${ }^{57}$ See Hunt \& Macleod, Outcomes, p 185.

${ }^{58}$ Hunt \& Macleod, Outcomes, p19. See, on the courts' persistence in seeking to overcome the objections of a child, pp 199-210.
} 
and assist and accommodate fathers' even if violent. ${ }^{59}$ Some Cafcass officers thought that there were courts that went too far; they said that judges were failing to take mothers' concerns seriously: 'When the courts get stroppy with mothers who won’t allow contact I sometimes think they don't stop enough and say well actually they might have a damn good reason for it'. ${ }^{60}$ The courts' persistence had the potential to expose children to conflict and to jeopardize their welfare and their relationships with their resident parents. Courts could be characterised as 'contact at all costs': 61

The no stone unturned as an approach of the court is something we are pulled up against again and again. 'Are you sure you have done everything?

${ }^{59}$ Solicitor interviewed by Hunt and Macleod, Outcomes. See for the comments of professionals p 190-191. See also Kaganas, 'Conflict, Contact and Risk’.

${ }^{60}$ Cafcass Officer, Hunt and Macleod, Outcomes, p 191.

${ }^{61}$ Hunt and Macleod, Outcomes, p191. The courts see themselves as following the advice proffered in welfare reports (Sir Mark Potter, then President of the Family Division, acting as chair, Current Legal Problems lecture 29 October 2009). However, it may be that professionals tailor their practice to take into account what advice or evidence the courts will find acceptable. Anderson found this to be the case in relation to solicitors (see L. Anderson, Contact Between Children and Violent Fathers: In Whose Best Interests? (London: Rights of Women, 1997) p16). James et al comment, in relation to representation of children's views, that CFRs construct their reports to conform to legal constraints and that they 'may find it difficult ...to reason outside the logic of this conceptual system. Consequently, it becomes extremely difficult for them to argue in the case of any individual child for the differences their particular circumstances may make to the determination of what is in the child's best interests' (A. L. James, A. James and S McNamee, 'Research — Turn Down The Volume? — Not Hearing Children In Family Proceedings’ [2004] 16 CFLQ 189, 200. 
Are you sure you couldn’t just observe or supervise a couple of contacts and that would unlock the situation'. ${ }^{62}$

The study shows that a high proportion of cases were resolved by means of consent orders. ${ }^{63}$ However the extent to which some of the consent orders reflected genuine agreement must be open to question. Resident parents were put under considerable pressure throughout the legal process. Solicitors worked to get the parties to agree to contact. ${ }^{64}$ Judges used their authority to impress on resident parents, even at the first appointment, that contact would be in the interests of the child. ${ }^{65}$ They sought to persuade the resident mother that allowing contact would be 'the right thing to do'; [Y]ou're cajoling, you're persuading, sometimes you think you're more like a social worker than a judge ${ }^{66}$ One of the judges interviewed said ${ }^{67}$ :

I think we have a number of cases where a mother will come back to court and say, there's been a consent order, she’s not abided by it and she’s come back and say she was forced into agreeing it, whether it's by her lawyers, or she feels she was forced by the court to agree. Yes, that does happen.

Resident parents who resisted would be subjected to renewed efforts to persuade them. Hunt and Macleod describe cases demonstrating considerable reluctance on the part of the courts

\footnotetext{
${ }^{62}$ Cafcass officer, Hunt \& Macleod, Outcomes, p 190.

${ }^{63}$ At least $85 \%$ of the orders made were by consent (Hunt \& Macleod, Outcomes, p 12)

${ }^{64}$ Hunt \& Macleod, Outcomes, pp 94, 171, 175.

${ }^{65}$ Ibid. p 95.

66 Ibid. p 194.

${ }^{67}$ Hunt \& Macleod, Outcomes, p 175.
} 
and the professionals to concede that the goal of securing contact might not be achievable in some cases: ${ }^{68}$

[T]he process of reaching "agreement" was often slow and fraught with difficulty as resident parents were encouraged, persuaded, pushed or forced into shifting their position. The impetus throughout from the court and Cafcass officers was to try to move contact on, sometimes in very inauspicious circumstances, and while the preferred approach was typically conciliatory a harsher line was sometimes evident when this failed to bring about the desired response. ${ }^{69}$

Given the pressure to which resident mothers were subjected, and the circumstances in which contact was ordered, it might be questioned whether the orders made were always appropriate. Indeed Hunt and Macleod's findings suggest they sometimes were not; there were cases $^{70}$ in which the court declined to enforce orders in the context of serious welfare concerns or resistance from the children.

The findings reported by Hunt and Macleod are consistent with earlier academic work suggesting that the assumption that children need contact frequently overshadows other considerations that affect children's welfare as well as that of mothers. ${ }^{71}$ It confirms that in many contested cases, the source of the conflict, and what appears to motivate resident

\footnotetext{
${ }^{68}$ Ibid. p165. See, for the description of the cases, pp160ff.

69 Ibid. p120.

70 Ibid. pp 71ff; pp 85-88. See also H. Rhoades, 'The "No-Contact Mother": Reconstructions of Motherhood in the Era of the "New Father"' (2002) 16 International Journal of Law Policy and the Family, 71.

${ }^{71}$ See, for example, C. Smart and B. Neale, 'Arguments Against Virtue - Must Contact be Enforced?’ (1997) Fam Law 332; C. Smart, ‘ The Legal and Moral Ordering of Child Custody’ (1991) 18 J of Law and Society 485 ; Kaganas, 'Contact, Conflict and Risk’;
} 
mothers' opposition to contact, are concerns about the non-resident parent's behaviour or parenting capacity. ${ }^{72}$ However, these concerns are often subordinated by professionals and judges involved in dealing with contact disputes to an apparently overriding imperative of maintaining contact. The problem is seen as residing in the mother and the solution is taken to lie in getting mothers to accede to contact.

Hunt and Macleod's study ended in 2006 but there is nothing to suggest that the prioritization of contact has changed or that the courts have become more circumspect in making orders. ${ }^{73}$ Admittedly there is now a requirement that courts scrutinize agreements before making consent orders. However in the light of the prevailing pro-contact ethos it cannot be certain that this will make contact safer or more sustainable in many cases. Mothers may even be deterred from voicing their fears or objections in the face of threats of imprisonment or

\footnotetext{
${ }^{72}$ See Rhoades, 'The "No-Contact Mother"' 71; S. Day Sclater and F. Kaganas 'Contact: Mothers Welfare and Rights' in A. Bainham, B. Lindley, M. Richards and L. Trinder (eds.), Children and Their Families (Oxford: Hart Publishing, 2003); F. Kaganas and S. Day Sclater, ‘Contact Disputes: Narrative Constructions of “Good” Parents’ (2004) 12 Feminist Legal Studies 1.

${ }^{73}$ A recent investigation conducted for the Sunday Times Magazine indicates that courts continue to ignore mothers' concerns: C. Toomey 'Mothers’ Ruin', The Sunday Times
} Magazine 2 August 2009 p 48, 53. There is as yet no available evidence on the working of the Revised Private Law Programme. This is supposed to evidence 'growing recognition of the impact of domestic violence and abuse, drug and alcohol misuse and mental illness' (Practice Direction. The Revised Private Law Programme, para 1.3; Revised Private Law Programme p1). The PLP requires Cafacass to undertake risk assessments in terms of s16A of the Children Act where the FCA suspects that a child is at risk of harm (Practice Direction. The Revised Private Law Programme, para 1.3; Revised Private Law Programme pp1and 5) and the court must scrutinise agreements before making consent orders (Practice Direction. The Revised Private Law Programme, para 1.3; Revised Private Law Programme p 8). 
removal of their children. ${ }^{74}$ And there appears to be a greater willingness on the part of the professionals and the courts to resort to such threats. Courts in particular are concerned not to be seen as allowing mothers to disobey orders.

\section{Restoring Public Confidence in the Courts: Dealing with 'Problem' Mothers}

One of the main problems complained of by fathers' rights groups is that contact arrangements are not adhered to and that courts cannot ensure compliance. That the courts have a limited impact on outcomes is confirmed by research conducted by Trinder and Kellet; they found that the amount of court intervention did not determine the amount of contact taking place in the cases they examined. ${ }^{75}$ Both resident and non-resident parents in their sample complained that court orders were not being obeyed. Non-resident parents said this was because resident parents were blocking contact or influencing their children against it. Resident parents maintained that non-resident parents were not sticking to dates and times. ${ }^{76}$

It is, however, largely non-compliant resident mothers rather than unreliable fathers who have attracted the courts’ attention. Mothers who oppose contact have been described as 'implacably hostile’ and they are often urged to change their ways. ${ }^{77}$ In addition, mothers who express serious concerns such as fear of violence appear to be regarded as potentially

\footnotetext{
${ }^{74}$ Toomey’s article ('Mothers' Ruin) quotes Mavis Maclean of the Oxford Centre for Family Law and Policy (Oxflap) as saying that mothers are often afraid to voice their anxieties for fear of being viewed as obstructive and of being deprived of residence as a result.

75 Trinder \& J Kellett, The Longer Term Outcomes, p 20

${ }^{76}$ Ibid. 43

${ }^{77}$ See, for example, Re D (A Minor) (Contact: Mother's Hostility) [1993] 2 FLR 1 (CA) 7-8. The obstacle to successful contact is often identified as an obstructive mother. See the professionals’ and judicial officers’ views quoted in Hunt \& Macleod, Outcomes, p193.
} 
manipulative and so suspect. ${ }^{78}$ The reported cases reflect an assumption that, unless a significant level of violence, or perhaps some other serious paternal deficiency is proved, it is obstructive mothers who are the problem ${ }^{79}$ requiring a solution. That solution is seen to lie in more effective measures to bring such mothers into line. ${ }^{80}$

While castigation of resident mothers is not new, and while the courts are still reluctant to enforce orders by transferring residence or by imprisoning mothers for contempt of court, ${ }^{81}$ they have begun to act more punitively. This response, it seems, may be attributed to a large extent to the activities of fathers’ rights organisations, or, more specifically, those of Fathers4Justice, which received widespread media coverage. The judiciary appears to have

${ }^{78}$ See, for a recent example SS v KS [2009] EWHC 1575 (Fam) where supervised interim contact was confirmed on appeal despite serious allegations, a past criminal conviction and an acknowledged risk of emotional abuse of mother and child. The court here stressed that findings of fact need only be held where the truth of the allegations would have a significant impact on the type of order to be made. The court also referred to the risk of false or exaggerated allegations. While it appears therefore that the number of fact-finding hearings has increased significantly, the protection afforded to mothers and children may not have. ${ }^{79}$ Re L (Contact: Domestic Violence) 351.

${ }^{80}$ See also Hunt \& Macleod, Outcomes, p197.

${ }^{81}$ See e.g. The Advisory Board on Family Law: Children Act Sub-Committee, Making Contact Work. A Report to the Lord-Chancellor on the Facilitation of Arrangements for Contact Between Children and their Non-residential Parents and the Enforcement of Court Orders for Contact (London: The Stationery Office) para 14.10.

14.10. But see A v N (Committal: Refusal of Contact) [1997] 1 FLR 533 (CA); F v F (Contact: Committal) [1998] 2 FLR 237 (CA). In B v S (Contempt: Imprisonment of Mother) [2009] EWCA Civ 548, [2009] 2 FLR 1005, Wilson, LJ, dismissing an appeal against a sentence of imprisonment said: The days are long gone when mothers can assume that their role as carers of children protects them from being sentenced to immediate terms of imprisonment for clear, repeated and deliberate breaches of contact orders' (para 16). He advised the mother not only to refrain from obstructing contact but to promote it (para 16). 
been concerned about the possibility of a loss of public confidence in the family justice system. They accordingly set out to rebut allegations that courts let mothers 'get away with' flouting orders.

In Re C (Residence Order) ${ }^{82}$ for example, the court found that the harm the child was suffering or would suffer if residence were not transferred to the father outweighed the harm she would suffer by being removed from the mother. The court referred to the protests of fathers in many cases coming before it that 'the court is powerless to enforce its orders, quite unable to control the intractable, implacably hostile mother'. It seemed to regard its decision in part as evidence to such fathers that the courts are not powerless:

Time after time this court has to mollify the angry father, endeavouring to explain that the judge has a broad discretion and that his decision cannot be challenged unless plainly wrong. This time the boot is on the other foot, and if a different conclusion has been reached in this case then let it be shouted out from the rooftops.

In $V \mathrm{v} V$ (Contact: Implacable Hostility) ${ }^{83}$ the court also transferred residence to the father. This transfer was effected despite the fact that the children wanted to stay with their mother, that the move would cause them 'emotional upheaval' and that the mother had, apart from the children's relationship with the father, 'more than adequately' met their needs. ${ }^{84}$ However,

\footnotetext{
82 [2007] EWCA Civ 866; [2008] 1 FLR 211 [24]. See also Re M (Intractable Contact Dispute: Interim Care Order [2003] EWHC Fam 1024; [2003] 2 FLR 636 for a case where residence was transferred.

83 [2004] EWHC Fam 1215; [2004] 2 FLR 851.

${ }^{84}$ Ibid. [45]-[46].
} 
what is most notable about this case is the judge's call for law reform. Bracewell J, clearly mindful of the publicity attracted by Fathers4Justice at the time said:

[4] There is a perception among part of the media, and some members of the parents' groups, as well as members of the public, that the courts rubber-stamp cases awarding care of children to mothers almost automatically and marginalise fathers from the lives of their children. There is also a perception that courts allow parents with care to flout court orders for contact and permit parents with residence to exclude the parent from the lives of the children so that the other parent is worn down by years of futile litigation which achieves nothing and only ends when that parent gives up the struggle, or the children are old enough to make their own decisions, assuming they have not been brainwashed in the meantime....

[6] ....Unreasonable parents, by definition, are difficult to deal with, and the most intractable situation is undoubtedly the unreasonable mother, but judges currently do not have the tools with which to make progress with the unreasonable mother or sometimes the unreasonable father who can flout or frustrate orders with impunity unless sent to prison.

The judge declared that changes were needed. For example, Cafcass should monitor contact arrangements and bring cases back to court if necessary. Legislation was needed to give courts the 'weapons' they needed to deal with a 'small group of obdurate mothers'. ${ }^{85}$ They should be able to refer parents to counselling, parenting programmes and classes. They should be able to make referrals to psychiatrists or psychologists. They should be able to order community service. For courts to 'give up' in the sense of making an order for indirect contact

\footnotetext{
${ }^{85}$ Ibid. [10].
} 
or no order at all was unacceptable: 'This option results in a perception fostered by the press that family courts are failing in private law cases and that family judges are anti-father. ${ }^{, 86}$

Similar calls for reform had previously been made by Munby $\mathrm{J}$ in Re D (Intractable Contact Dispute: Publicity). ${ }^{87}$ He too referred to media coverage and the 'risk [of] forfeiting public confidence'. 'We ignore the media at our peril', ${ }^{88}$ he warned and went on to advocate 'swift, efficient enforcement of existing court orders' ${ }^{89}$

Media reports of the type referred to by Munby $\mathrm{J}$ have prompted the courts, in a bid to defend themselves against claims of bias, ${ }^{90}$ unfairness and secrecy, ${ }^{91}$ to direct some of their fire at a different problem: irresponsible or dangerous fathers. However, while judges are ready to point out the shortcomings of some fathers in order to correct misconceptions about the probity of the family justice system, the legal system has, in the main, focused on showing that it is willing to punish 'bad' mothers. ${ }^{92}$ The calls for 'better' enforcement measures were not directed at getting unreliable or indifferent fathers to visit and take responsibility for their children. The request for more powers was primarily motivated by a wish to control mothers

\footnotetext{
${ }^{86}$ Ibid. 10].

${ }^{87}$ [2004] EWHC Fam 727; [2004] 1 FLR 1226.

${ }^{88}$ Para 4.

${ }^{89}$ Para 56.

${ }^{90}$ See, for example, Re O (Contact: Withdrawal of Application) [2003] EWHC 3031 (Fam), [2004] 1 FLR 1258 at 1260; Re M (Intractable Contact Dispute: Interim Care Order) [2003] EWHC Fam 1024; [2003] 2 FLR 636 para 23; Re W (Permission to Appeal) [2007] EWCA Civ 786, [2008] 1 FLR 406; Re Bradford; Re O’Connell [2006] EWCA Civ 1199; [2007] 1 FLR 530 para 97.

91 The Family Courts have now been opened up to the media.

${ }^{92}$ See also S. Adams, ‘Parents’ Rights v Children’s Needs in Private Cases’ [2007] Fam Law 257, 261.
} 
and, in doing so, to restore public confidence in the ability of courts to ensure that their orders would be complied with. These judicial demands reflect a newly emerging belief that the courts can be effective in 'making contact work' 93 provided that they play a different role from their traditional one and provided this role is facilitated by different powers.

\section{A Therapeutic approach - 'outcomes that are sustainable, that are in the best interests of children'}

That ultimately it is the court that has to make contact work is not in doubt as far as policymakers are concerned. It is agreed that courts are still the arena in which contact cases, and in particular the most intractable ones, should be decided. Making Contact Work ${ }^{94}$ states:

1.8 There will, of course, always be a role for the court to play in making contact work. The court remains the one institution which has both the authority to define and the power to impose a solution which is in the interests of the child.

The pressing question, however, has become how to ensure that the solution is an enduring one. It is not enough that the court makes a determination; what matters is that resident parents comply with the order.

\footnotetext{
93 The notion of making contact work was central to the Labour government's policy on contact. See eg The Advisory Board on Family Law: Children Act Sub-Committee, Making Contact Work.

${ }^{94}$ The Advisory Board on Family Law: Children Act Sub-Committee, Making Contact Work.
} 
It is still the case that the courts remain a last resort and the preference is still for agreement. In a Practice Direction issued by the President of the Family Division, the aim is stated as follows:

1.7 The Revised Programme is designed to assist parties to reach safe agreements where possible, to provide a forum in which to find the best way to resolve issues in each individual case and to promote outcomes that are sustainable, that are in the best interests of children and that take account of their perspectives. ${ }^{95}$

What is new here is a concern not only with consensus and compliance but with sustainable outcomes. Where conflict persists and non-compliance is a problem, it is the court that has to be the final arbiter. It is therefore imperative that the courts maintain their authority and so retain public confidence in their ability to dispense justice. Making Contact Work alludes to this:

14.47 We agree with the majority view that where a contact dispute is part of a court process and results in a court order, the court needs to retain its powers to compel obedience to its orders, and that fines and imprisonment are part of that process.

Nevertheless, these measures are considered inappropriate in most cases. ${ }^{96}$ Making Contact Work acknowledges that they 'are not only crude methods of enforcement; they are wholly inadequate as a means of addressing the problem of contact orders which have not been

\footnotetext{
${ }^{95}$ Practice Direction. The Revised Private Law Programme, This recapitulates The President's Guidance. The Revised Private Law Programme (2009), Introduction. 96 The Advisory Board on Family Law: Children Act Sub-Committee, Making Contact Work, para 14.47.
} 
implemented'. ${ }^{97}$ Different, more 'effective' powers, on the other hand, could facilitate

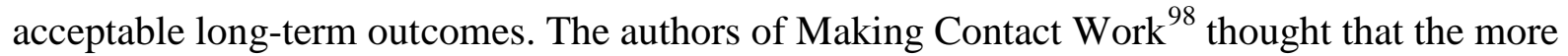
punitive the measure, the less likely it would be to succeed and that success might lie in court ordered parent education and a more 'therapeutic' approach to help parents to 'work though difficulties, hostilities etc' ${ }^{99}$

It is not only policy-makers who have held these views. The courts themselves have not seriously challenged the legitimacy of the expectation that they should act as a key resource for making contact 'work'. ${ }^{100}$ That contact problems might be insoluble where parents are deeply conflicted is something that neither those working in the legal system ${ }^{101}$ nor government have been willing contemplate. That the family justice system might be of little use in resolving matters satisfactorily or at all is something that, ultimately, cannot be conceded; ${ }^{102}$ to do so would surely damage public confidence in it irrevocably. What might be seen as a fundamental mismatch between what courts can do and what makes contact 'work' has instead been characterised as a problem with a solution.

\footnotetext{
${ }^{97}$ Ibid. para 14.48

${ }^{98}$ Citing Walker et al, Picking up the Pieces.

${ }^{99}$ Ibid. para 14.22. There are also concerns about violence; contact needs to be safe and of 'good quality', according to the Children in Families Committee (cited by the Rt Hon Lord Justice Wall ‘Making Contact Work in 2009’ [2009] Fam Law 590, 594.

100 Even Thorpe LJ in Re L (Contact: Domestic Violence) (see below) accepted that it would be unrealistic to expect otherwise.

${ }^{101}$ Solicitors interviewed by Hunt and Macleod also felt that 'something' had to be done to improve enforcement (Outcomes, p 208).

${ }^{102}$ But see Thorpe LJ in Re L (Contact: Domestic Violence), who comes close to this point.
} 
The solutions adopted, education and therapeutic intervention, ${ }^{103}$ while consistent with the aim of 'persuading' parents to obey orders, ${ }^{104}$ are consistent also with the perception that it is the underlying conflict that makes contact fail and with the recent observation that, even if contact is happening, it is not necessarily 'working: 'Ongoing parental conflict, particularly surrounding the child, and actual, or alleged, parenting deficits are likely to be make contact a very fraught and difficult experience for children and is damaging to children’s wellbeing'. ${ }^{105}$ Reporting on their recent research, Trinder and Kellett_warn that what matters for children is not how much contact they have but that they have 'good' contact. ${ }^{106}$

One attempt at persuasion in the form of education took the form of the Family Resolution Pilot Project. The scheme incorporated an initial risk assessment at court, parent education groups led by Relate and parent planning meetings with Cafcass officers. ${ }^{107}$ The project was not adjudged a success ${ }^{108}$ but the researchers evaluating it found that the group sessions where

${ }^{103}$ Court orders themselves might be regarded as serving a therapeutic function: H. Reece, 'Parental Responsibility as Therapy’ [2009] Fam Law 1167.

104 The Advisory Board on Family Law: Children Act Sub-Committee, Making Contact Work, para 14.22 .

105 Trinder \& Kellett, The Longer Term Outcomes, p 51.

${ }^{106}$ Ibid. p 51.

${ }^{107}$ L. Trinder, J. Kellett, J. Connolly and C. Notley, Evaluation of the Family Resolutions Pilot Project, Research Report 720, Executive Summary (London: DfES Publications. 2006) p 4.

${ }^{108}$ FAIns and the Family Resolution Pilot Project which were intended to promote a more holistic, educational and agreement orientated approach have not been deemed successful. See Trinder et al, Evaluation; J Walker, P McCarthy, S Finch, M Coombes, M Richards and C Bridge with K Laing, A Melville, S Kitchen, N Wood, S Raybould, C Wren, S Day- Sclater and P Webber, The Family Advice and Information Service: A Changing Role for Family Lawyers in England and Wales? Final Evaluation Report (Newcastle: Newcastle Centre for Family Studies, 2007). 
education and information were imparted had some positive effects. Some parents reported that they had learned about the impact of separation on children and what would be best for the family. ${ }^{109}$ Parental relationships improved and there was some rethinking of attitudes. ${ }^{110}$ However there was no evidence that this would lead to a change in behaviour or improved communication. Nor was there evidence that the limited benefits reported extended to high conflict cases. ${ }^{111}$ The researchers evaluating the project recommended that special provision be made for the most conflicted parents:

The family justice system should develop a range of parenting interventions including basic parent education and higher conflict education/therapeutic interventions to work alongside processes for dispute resolution and child involvement ${ }^{112}$

Similarly, Trinder and Kellett state that 'good' contact requires parental co-operation and that interventions should therefore be directed at effecting 'attitudinal and behavioural change'. ${ }^{113}$ They found that, 'Agreements and court orders alone are likely to increase significantly the chances of contact occurring but are far less likely to shift parental attitudes and

\footnotetext{
109 Trinder et al Evaluation p57.

${ }^{110}$ Ibid. p57-8.

111 Ibid. p 78, 80

112 Ibid. p102

113 Trinder \& Kellett, The Longer Term Outcomes, 51.
} 
behaviour. ${ }^{114}$ Therapeutic services, they thought, rather than conciliation or mediation can address the problems posed by 'parental attitudes and the parental alliance'. ${ }^{115}$

So, the demand now is for a solution to a different problem. In the past, the problem was conceived of as a defective, conflict-promoting divorce process centred on fault-based grounds. ${ }^{116}$ The solution was to change the divorce law. More recently the problem was characterised as the lack of varied and broad powers of enforcement. The solution identified was to increase those powers. And the solution for the problem of obdurate resident parents has been thought to be to vest the court not only with the power to punish disobedience but also to send parents for interventions designed to change their minds and attitudes. The issues are no longer simply the objective absence of contact or the resort to litigation. Now it is the underlying cause of contact difficulties that is perceived as the problem: the relationship between the family members and the impact it has on their behaviour. What is needed is not only compliance with orders but also 'good' conflict-free contact. This can be achieved only if the parents' relationship problems are addressed, whether therapeutically by means of counselling, or by educating parents. The aim of the Labour government, therefore, was to discover 'how to shift the attitudes of some parents better to focus on the needs of the child and how to develop advice, information, mediation, conciliation and enforcement processes that are much better at doing so'. ${ }^{117}$ The assumption was and remains that even if contact is

\footnotetext{
${ }^{114}$ Ibid. 51. See also Hunt \& Macleod who observe that pressure to agree from solicitors might lead resident parents to shift their position but not their attitude (Outcomes, p 94). See also Hunt \& Macleod p 147.

115 Trinder and Kellett, The Longer Term Outcomes, 52. See also B Cantwell 'In Practice: The Emotional Safeguarding of Children in private Law' [2010] Fam Law 84.

${ }^{116}$ See Cretney, Family Law in the Twentieth Century, p 386ff

117 DCA, DfES and DTI, Parental Separation: Children's Needs and Parents' Responsibilities. Next Steps, para 14. education and information are also central to the
} 
not working well (or at all), intervention can make it work (or make it work better). And it appears that the family justice system is considered to have a part to play in this process.

\section{Outcome Focused Courts}

It is not envisaged that the courts should be directly involved in seeking to change attitudes. ${ }^{118}$ Objections to their crossing well-established boundaries in this way today are much the same as they were nearly a century ago when the possibility was raised. Cretney ${ }^{119}$ records the reform efforts in the late 1920s and early 1930s of Claude Mullins, a Metropolitan Police Magistrate, which, he says:

raised important questions about the proper role of the legal system - in particular, about the relationship between, on the one hand, the court's basic role in adjudicating on disputes in accordance with established legal norms, and, on the other, the extent and nature of their

recommendations of the Family Law Review, Every Family Matters. Resort to parent education has been made elsewhere too. In Australia, parents are put into a Child Responsive Program before the case reaches the court. This program entails each parent watching a parent education DVD and then discussing their concerns and plans for child care with a Family Consultant, who is a social science specialist. Parents reported high levels of satisfaction with the Child Responsive Program and reported improved co-operation and a reduction in minor conflict. (J McIntosh and C Long (2007) The Child Responsive Program, operating within the Less Adversarial Trial: A Follow Up Study of Parent and Child Outcomes. Report to the Family Court of Australia, Victoria: Family Transitions). However, there is no indication in the research assessing the program as to the proportion of these parents whose relationships could be characterised as high conflict. Moreover the effect on children, especially those in shared care arrangements, was not necessarily beneficial.

118 See e.g. Trinder \& Kellett, The Longer Term Outcomes, 53

${ }^{119}$ S. Cretney 'Marriage Saving and the Early days of Conciliation - The Role of Claude Mullins [1998] 10 CFLQ 161 
involvement in the provision of guidance, counselling and other forms of assistance to those with problems in their personal relationships. ${ }^{120}$

Mullins believed that the courts were wrong to see domestic disputes exclusively through a legal lens. Instead the courts should provide some form of extra-legal assistance. ${ }^{121} \mathrm{He}$ wanted to introduce changes that would entail the court playing a therapeutic role: judges would advise and counsel the parties. In performing these functions, clearly 'the court was to go far beyond its traditional role of applying ascertainable legal rules'. ${ }^{122}$

Cretney observes that proposals of this nature attracted criticism from lawyers and officials within the legal system. ${ }^{123}$ Such an approach was considered contrary to the proper administration of justice; it would confer on the court 'functions of a non-judicial, advisory and patriarchal character' that would be better carried out by some other organisation. ${ }^{124}$ The Harris Committee, ${ }^{125}$ which was set up to enquire into social services in the administration of justice, including conciliation, rejected any 'blurring of the distinction between adjudication and social work' and took the view that conciliation should be the preserve of the probation service. ${ }^{126}$

\footnotetext{
${ }^{120}$ Ibid. p 165.

${ }^{121}$ Ibid. p 166.

${ }^{122}$ Ibid. p 167

${ }^{123}$ Ibid. p 167
}

${ }^{124}$ Viscount Sankey, the Lord Chancellor, quoted by Cretney 'Marriage Saving', p 168

${ }^{125}$ Report of the Committee on Social Services in Magistrates Courts (Chairman: SW Harris (1936)) Cmd 5122 para 18, (cited by Cretney, ‘Marriage Saving’ p 174).

${ }^{126}$ J. Doughty 'From Court Missionaries to Conflict Resolution: A Century of Family Court Welfare’ [2008] 20 CFLQ 135. Mullins' suggestions were rejected. The most the court could do would be to identify which cases were suitable for conciliation (in the sense of reconciliation) and it would be the probation service that would deal with them. The courts 
This dislike of venturing too far from the traditional role of the court was echoed in 1976 by the Law Commission which stated that the 'primary function of any court is adjudication, and, while that certainly does not exhaust its functions, a careful limit must be set to any functions going beyond adjudication’. ${ }^{127}$ Similarly, the Finer Report distinguished the English view of a family court from that held in America, where such courts saw themselves 'to be as much a therapeutic agency as a judicial institution'. ${ }^{128}$ In setting out the main criteria for a family court, the Committee included the requirement that it 'must be an impartial judicial institution, regulating the rights of citizens and settling their disputes according to law' and applying a 'uniform set of legal rules'. ${ }^{129}$ That it should be a judicial institution which, 'in dealing with family matters, does justice according to law', was a 'fundamental principle' and, perhaps, 'so obvious a point as hardly to be worth mentioning'. ${ }^{130}$ To 'expand and systematise the welfare function, which is an essential part of the family court concept, carries risks, as well as potential advantages, which can be eliminated only by clear thinking and firm practice regarding boundaries'. ${ }^{131}$ The Committee went on to say that the court should not see people as "”clients" and still less as "patients" for whom the court process is one form of, or a preliminary to, "treatment" ....The aim must be to make adjudication and welfare march hand

could supervise in a way consistent with the judicial function (Committee on Social Services in Magistrates Courts para 18, cited by Cretney, 'Marriage Saving' p 174 ).

127 Law Commission (Law Com No 77, Report on Matrimonial Proceedings in Magistrates' Courts, at para 4.12 .

${ }^{128}$ DHSS (1974) Report of the Committee on One-Parent Families Cmnd 5629, Vol 1 (London: HMSO) para 4.281-2.

${ }^{129}$ Ibid. para 4.283

${ }^{130}$ Ibid. para 4.285.

${ }^{131}$ Ibid. para 4.285. 
in hand but there should be no blurring at the edges’. ${ }^{132}$ And when the Children Act 1989 was being conceived, there was no significant support for judicial counselling or advice. The Law Commission declined to entertain suggestions that judges should mediate between parties and use their attendance at court as an opportunity to 'suggest solutions and assist in reaching agreement': ${ }^{133}$

[I]f the judge tries to promote a particular policy or view of the best arrangements, for example with regard to joint custody or the level of access, this could be thought incompatible with the requirement that each case be judged on its own individual merits in the light of all the circumstances. There is even a risk ... that particular "hobby horses" will be ridden without outside scrutiny or a real opportunity to challenge. Essentially, therefore, these functions are more suitable for skilled welfare officers or social workers, and should not be expected of judges whose main task is to adjudicate upon disputes. ${ }^{134}$

While judges nowadays seem to dispense advice and promote their views about what is best for children in a way that the Law Commission could not have envisaged, they still agree with the consensus that they should not be in the business of providing counselling. They have for some time seen it as their role to promote settlements, to chide, threaten and occasionally punish family members in a bid to change behaviour. But changing minds or relationships is not something they see themselves as equipped to do. For example in one reported case the judge noted: 'This is a court of law....[A]ll I can do is determine disputes. It is up to the

\footnotetext{
132 Ibid. para 4.285.

133 The Law Commission, Working Paper no 96 Family Law: Review of Child Law: Custody (London: HMSO, 1986) para 4.8(f).

${ }^{134}$ Ibid. para 4.9(f).
} 
parents to parent Y in a way that does not harm him. ${ }^{\text {,135 }}$ The parents, the judge continued, need to 'voluntarily engage in some process to improve their relationship' ${ }^{\text {'36 }}$ Similarly Wall LJ has recently reiterated the limits of the judicial function:

If we have learned anything in the last 10 years it is, surely, that we must be able to foster contact non-forensically, that is to say, outside the courtroom. The court can act as the fact finder ..... It can properly decide what is in the best interests of a child. But the court cannot educate, the court cannot mediate: above all the court cannot work with parents, let alone children on a one to one basis over time outside the courtroom. This is the field of social work, and in the most difficult case, mental health expertise. ${ }^{137}$

In $R e L$, Thorpe $\mathrm{L} \mathrm{J}$ made it clear that he did not think the court's powers extended to regulating relationships ${ }^{138}$ and went on:

${ }^{135}$ Re A (Leave to Remove: Cultural and Religious Considerations) [2006] EWHC 421 (Fam), [2006] 2 FLR 572 [57].

${ }^{136}$ Ibid. [58]. Even the more informal and interventionist approach observed among some judges in Scotland by Raitt seems directed more at informing judicial decision-making or facilitating settlement than changing minds. However at least one judge interviewed about his willingness to speak to children involved in contact disputes appeared to see himself as playing a therapeutic and problem-solving role rather than as imposing decisions:

'We get the parents round the table. We try to find out what the problem is. We try and find out how we can help cure that problem and we take it from there.... Basically the idea is a therapeutic form of justice, non-adversarial, trying to get problems...trying to get parents to solve them for the children'136 (F. Raitt, 'Hearing Children in Family Law Proceedings: Can judges Make a Difference?’ [2007] 19 CFLQ 204, 217)

${ }^{137}$ Wall 'Making Contact Work in 2009'.

${ }^{138}$ Re L (Contact: Domestic Violence) p 364. 
[T]here is in my opinion validity in questioning the future role of the family justice system in relation to contact. I have already expressed how limited is the capacity of the family justice system to produce good outcomes in disputed areas of personal relationship.... [Contact] disputes are particularly prevalent and intractable. ....The disputes are often driven by personality disorders, unresolved adult conflicts or egocentricity. These originating or contributing factors would generally be better treated therapeutically, where at least there would be some prospect of beneficial change, rather than given vent in the family justice system.... ${ }^{139}$

The court's capacity to resolve the challenge of what has been called the implacably hostile parent is evident. The practical difficulties posed by the power to commit are obvious. Treatment rather than imprisonment would seem more likely to succeed. However if it be unrealistic to question the continuing role of the family justice system in promoting postseparation contact then I would express the hope that the newly created Children and Family Court Advisory and Support Service (CAFCASS) be given a role to address those aspects of the fractured relationships that the court in the exercise of its statutory and inherent powers cannot approach. ${ }^{140}$

Thorpe LJ gave expression to the new preoccupation with outcomes as well as to the hope that therapeutic intervention could be used to address the underlying problems fuelling the dispute and to heal relationships. But he was careful to stress the unsuitability of the legal system for these purposes. Hughes LJ, writing extra-judicially, made it clear that in his view the court is a neutral fact-finder concerned with the application of rules. He said that litigation

\footnotetext{
${ }^{139}$ Ibid. p 366.

140 Ibid. p 367.
} 
in the family courts 'is not so different'. ${ }^{141}$ 'In essence', he thought, 'children litigation is like any other litigation; it is about bringing competing cases to a neutral seat of judgment'. It is 'about the legal rules for resolving issues about child welfare'. All that has changed is that judges now regard themselves as case managers as well as decision-makers. They control evidence, they give directions and they set a timetable.

Nevertheless, despite all these disclaimers and expressions of aversion to anything other than neutral fact-finding, judges are increasingly seeking to manage cases in a way that not only leads to efficient decision-making but to securing a particular outcome: sustainable contact. ${ }^{142}$

That the courts feel that their role is to achieve that particular outcome can be seen from the research of Hunt and Macleod. They record numerous cases where courts made enormous efforts to get contact going. Judges called for welfare reports and psychological assessments. They ordered supervised contact. They listed cases for review. They were not merely making decisions about whether there should be contact orders and if, so what form contact should take. Indeed some of those professionals interviewed for the study thought that at times the courts tried too hard; ${ }^{143}$ they were attempting to ensure that contact happened and, perhaps, even that it 'worked'.

\footnotetext{
141 The Rt Hon Lord Justice Hughes 'The Children Act 1989: A Different Sort of Litigation?' [2008] Fam law 1008, 1015.

142 Both judicial job dissatisfaction and a perceived loss of public confidence in the courts have been identified as key factors in the drive to establish problem-solving courts (J. Nolan Jr, Legal Accents, Legal Borrowing. The International Problem-Solving Court Movement (Princeton: Princeton University Press, 2009) pp 8-9).

${ }^{143}$ Hunt \& Macleod, Outcomes, p222.
} 
The reported cases likewise show that the courts have been active in trying to achieve the desired outcomes. In Re C (Contact Order: Variation) the court, albeit dealing with a technical matter, said: 'Where a contact order is not operating smoothly, the court that made the order has a continuing responsibility to strive to make it work' ${ }^{144}$ To this end, the courts have referred cases to the NYAS; ${ }^{145}$ they have recommended anger management to abusers; and they have instructed mothers to attend counselling, even, in at least a few reported cases, where domestic violence had been proven. ${ }^{146}$

Now an even more outcome-oriented role for the court is being developed. In the Midlands, family judges and magistrates have drafted a statement of 'judicial expectations' for those parents who come to court. ${ }^{147}$ This is intended to make clear to parents not only that they are expected to come to an agreement about contact, but that they must agree arrangements considered 'appropriate' by the court. To allow parents to assume that disputes are decided on a case by case basis and in accordance with the paramountcy principle is regarded as 'unhelpful' because it allows parents 'the freedom to contemplate an outcome (and become entrenched in that view) when that outcome might be far away from that which a court would be contemplating'. ${ }^{148}$ Mr Justice McFarlane, recommending that a national statement of

\footnotetext{
144 [2008] EWCA Civ 1389; [2009] 1 FLR 869 [13].

145 See, for example, Re A-H (Contact Order) [2008] EWCA Civ 630, [2008] 2 FLR 1188. 146 See, for example, Re A-T (Children) [2008] EWCA Civ 652, [2008] All ER (D) 164
} (May) (CA) However in this case the judge's order was overturned; there were no counsellors available.

${ }^{147}$ Midland Region Family Judges and Magistrates (2009) What the Family Courts Expect from Parents http://www.hmcourts-service.gov.uk/cms/files/family_final.pdf (accessed 30 April 2010).

${ }^{148}$ E. Walsh. 'Newsline Extra: Parental Responsibility: A National Statement' [2009] Fam Law 632, 633. 
judicial expectations be devised, has argued that this initiative must be 'judge driven and driven by judges alone'. Every parent should understand 'that the judges themselves (rather than being blank ciphers) have expectations of how a parent should discharge their responsibility in these circumstances' ${ }^{149}$

Those expectations are clearly expressed:

The court therefore expects you to do what is best for your child:

- Encourage your child to have a good relationship with both of you.

- Try to have a good enough relationship with each other as parents, even though you are no longer together as a couple.

- Arrange for your child to spend time with each of you. ${ }^{150}$

For parents who do not come to the 'right' agreement, other measures are in place. Among these are education and therapeutic intervention and courts, while they still 'outsource' these services, are expected to make greater use of them. In 2000 Douglas et al ${ }^{151}$ recommended that courts should act as an 'initial information resource and referral point', directing parents and children on a voluntary basis to services such as counselling. ${ }^{152}$ The arrangements in place come close to this. Courts hearing more difficult cases are expected to consider the need for therapeutic intervention; the Practice Direction governing cases involving allegations of domestic violence empowers the court, with the consent of the person concerned, to direct

\footnotetext{
149 Ibid. 633.

${ }^{150}$ Midland Region Family Judges and Magistrates, What the Family Court Expects (bold in original).

${ }^{151}$ G. Douglas, M. Murch, L. Scanlon and A. Perry, ‘Safeguarding Children’s Welfare in Non-Contentious Divorce: Towards a New Conception of the Legal Process' [2000] 63 MLR 177.

152 Douglas et al, 'Safeguarding’, p 193-4.
} 
a party to seek advice or treatment. ${ }^{153}$ The Practice Direction issued in terms of the revised Private Law Programme requires the court at the first hearing in all cases to consider ' $[\mathrm{w}]$ hat other options there are for resolution e.g. may the case be suitable for further intervention by Cafcass; mediation by an external provider; collaborative law or use of a parenting plan? ${ }^{154}$ It also refers to the requirement that consideration be given to attendance at Parenting Information Programmes or other activities, whether court ordered in terms of s11 of the Children Act as amended or not. ${ }^{155}$

In terms of the amendments to the Children Act 1989, the courts can order litigants to seek help to change their behaviour and the courts can punish them if they do not seek that help or, indeed, if they do not change. It is the behaviour of the litigants and its cause, the bad state of their relationship, that need to be addressed. The courts are cast in a key role as part of the problem solving machinery.

The legislation creates new orders and new measures to penalize breaches. A court hearing a contact case can make contact activity directions ${ }^{156}$ and, on making a contact order, can impose contact activity conditions. ${ }^{157}$ A person subject to a contact activity direction or condition is required to 'take part in an activity that promotes contact.' ${ }^{158}$ This could include attendance at:

\footnotetext{
153 Practice Direction (Residence and Contact Orders: Domestic Violence and Harm).

${ }^{154}$ Practice Direction, The Revised Private Law Programme, para 5.2(c).

155 Ibid. para 5.2(d).

156 Section 11A Children Act 1989.

157 Section 11C. The same applies when the court varies a contact order.

${ }^{158}$ Sections $11 \mathrm{~A}(3)$ and $11 \mathrm{C}(2)$.
} 
(a) programmes, classes and counselling or guidance sessions of a kind that-

(i) may assist a person as regards establishing, maintaining or improving contact with a child;

(ii) may, by addressing a person's violent behaviour, enable or facilitate contact with a child;

(b) sessions in which information or advice is given as regards making or operating arrangements for contact with a child, including making arrangements by means of mediation. ${ }^{159}$

The court may ask a Cafcass officer to monitor compliance with contact activity directions or conditions and to report any breach. ${ }^{160}$ Compliance with contact orders may also be monitored and a Cafcass officer can be charged, for up to a year, with reporting breaches of these too. ${ }^{161}$ Breach of a contact activity condition or a condition attached to a contact order under s 11(7) of the Act constitutes breach of a contact order. ${ }^{162}$ Any breach of a contact order may lead to the making of an enforcement order imposing on the parent an unpaid work requirement. ${ }^{163}$ Compliance with that too can be monitored. ${ }^{164}$ The power to impose an unpaid work requirement is in addition to the courts' normal powers to punish for contempt of court as well as the power to transfer residence from one parent to another. Doubtless, judges will also continue to use less coercive methods; they will still seek to persuade non-compliant mothers by impressing on them the need to do the 'right thing'.

\footnotetext{
${ }^{159}$ Section $11 \mathrm{~A}(5)$. See also s11C(5).

160 Section $11 \mathrm{G}$.

161 Section $11 \mathrm{H}$.

162 Children and Adoption Act 2006, Explanatory Notes, para 30.

${ }^{163}$ Section 11J. There is also a power to order financial compensation for financial loss caused by a breach (s110).

${ }^{164}$ Section $11 \mathrm{M}$.
} 
In order to give effect to the reforms, the $\mathrm{DCSF}^{165}$ commissioned provision for parenting programmes- Making Contact Safe, Making Contact Work - 'designed to support attending parents with information on the divorce process, how it can affect them and their children and how to change things for the better. The intention is to encourage safe contact between a child and an individual by the end of the programme'. ${ }^{166}$ These typically involve two two-hour groupwork sessions. ${ }^{167}$ There are also intensive, 60 hour long, domestic violence perpetrator programmes. ${ }^{168}$ Finally, information about mediation is provided through the Legal Services Commission. ${ }^{169}$

The court must consider the suitability of the party to engage in the activity prescribed. In practice the Cafcass officer will be likely to have suggested to the court that an activity might be beneficial. ${ }^{170}$ The attitude of the person concerned will be a 'key consideration'. In the case of parenting information both parties are required to attend albeit separately. In the case of domestic violence programmes the person concerned is required to attend if he has conceded

165 The DCSF has also designated 10 pilot areas in a project designed to determine how best local services can be co-ordinated for divorcing and separating parents: E. Walsh, 'Newsline Extra: Support for Separated Parents’ [2009] Fam Law 1220.

${ }^{166}$ DCSF (undated) 'Government Response to the consultation on the proposals for the new subsidy arrangements to support individuals taking part in contact activities directed or so ordered by the courts' p7

(www.dcsf.gov.uk/.../Contact\%20Activity\%20Summary\%20of\%20Responses\%20Final.doc, accessed 10 May 2010).

${ }^{167}$ Guidance to Cafcass Practitioners on their roles in supporting the courts in their use of the section 11A provisions, Children Act 1989 (as inserted by the Children and Adoption Act 2006) para 2.2. Resolution is piloting information workshops: G. Morris, 'Resolution:

Parenting After Parting: Information Workshops for Parents’ [2009] Fam Law 984.

${ }^{168}$ Guidance to Cafcass Practitioners, para 2.2.

169 DCSF, Government Response, p7.

${ }^{170}$ Guidance to Cafcass Practitioners, para 2.4. 
his violence or has been found through a finding of fact process to have been violent. It is intended that support services will also be offered to the victim and current partner of the perpetrator. ${ }^{171}$

The extent to which the new powers are being used is yet to be documented but anecdotal evidence suggests that little use has been made of them. ${ }^{172}$ In addition, it appears that the kinds of intervention available are limited. It is also thought that funding to enable people to attend programmes is a problem. ${ }^{173}$ Nevertheless, the potential for use is there. And the existence of these measures points to a change in the function of the family court. The use by the judiciary of their authority to persuade parents to change their behaviour, their newer concern with addressing underlying problems in order to secure particular outcomes and the new powers created by the legislation, mean that the family courts now have some of the characteristics of problem solving courts.

\section{Problem-Solving Courts}

The concept of problem-solving courts animated by the theories and practices of therapeutic jurisprudence ${ }^{174}$ is well-established in the USA. According to Nolan, ${ }^{175}$ these courts address

\footnotetext{
${ }^{171}$ Ibid. para 2.5.

172 B. Sayers, 'In Practice: Contact Activities' [2009] Fam Law 617.

${ }^{173}$ Personal communication from Adrienne Barnett, barrister, Sept 2009.

174 Therapeutic jurisprudence requires a multidisciplinary response to problem behaviours. It requires that judges refer people for treatment with and that they become involved in monitoring (M. Alberstein, 'Therapeutic Keys of Law: Reflections on the Power and Limitations of an Alternative Movement, A Book Review of Judging in a Therapeutic Key: Therapeutic Jurisprudence and The Courts’ (Bruce J. Winick and David B. Wexler, eds.)' (2006) 39 Israel Law Rev. 140, 148).

${ }^{175}$ Nolan, Legal Accents, p 10.
} 
the problems of individual parties, usually offenders. They also address the problem of the perceived need for the court system to regain legitimacy in the wake of a feared loss of public confidence. In addition they step in where social institutions have failed to address social ills. To this end they use, among other strategies, judicial monitoring, a therapeutic orientation, a change in traditional judicial roles and an emphasis on solving the underlying problems of parties. $^{176}$

Problem-solving courts are predicated on the belief that courts can play a part in finding solutions to problems, that outcomes and not just process and precedent matter. As an American judge explains, they aim to 'achieve more constructive interventions than conventional case resolutions, which often do not solve the underlying problem...that brings the same people back to court again and again'. ${ }^{177}$ There is a 'recognition that the coercive power of courts can change people's behaviour ${ }^{, 178}$ and there is an emphasis on compliance monitoring, in which the judge is involved, ${ }^{179}$ with 'clear consequences for noncompliance'. ${ }^{180}$ Judges, who speak directly to offenders, use their status to 'encourage

\footnotetext{
${ }^{176}$ Ibid. p 11.

177 J. S. Kaye, ‘Delivering Justice Today: A Problem-Solving Approach’ (2004) 22 Yale L. and Policy Review 125.

${ }^{178}$ R. V. Wolf, ‘Don’t Reinvent the Wheel. Lessons from Problem-Solving Courts', (New York: The US Department of Justice's Community-Based Problem-Solving Criminal Justice Initiative. Center for Court Innovation. Bureau of Justice Assistance, 2007) p1 (http://www.courtinnovation.org/_uploads/documents/Dont\%20Reinvent.pdf, accessed 11 May 2010).

${ }^{179}$ G. Berman and J. Feinblatt 'Problem-Solving Courts: A Brief Primer' (2001) 23 Law and Policy 125, 129.

${ }^{180}$ Wolf, ‘Don’t Reinvent the Wheel’ fig, 1.
} 
offender compliance’, to ‘support collaboration' between agencies and to move beyond process to outcome. ${ }^{181}$

Alberstein tells us that:

They represent a shift in the perception of the role of courts, which are not only expected to resolve the dispute before them, but also to attempt to address the variety of human problems which are responsible for bringing the case to court. By dealing with the underlying problem which is responsible for the immediate dispute, courts are supposed to prevent recurring court involvement for the individuals before them. ${ }^{182}$

Berman and Feinblatt say that:

Problem-solving courts.... seek to broaden the focus of legal proceedings, from simply adjudicating past facts and legal issues to changing the future behavior of litigants and ensuring the future well-being of communities. ${ }^{183}$

However Berman and Feinblatt also draw attention to some of the disadvantages. They raise the possibility that problem solving judges might impose treatment regimes on defendants 'without reference to the complexity of individual's problems. ${ }^{184}$ They also suggest that punishments for defendants who fail to comply might be harsher than those they would have

\footnotetext{
${ }^{181}$ Ibid, p 7. See also M. Burton, 'Judicial Monitoring of Compliance: Introducing "Problem Solving” Approaches to Domestic Violence Courts in England and Wales' (2006) 20 Int J of LP\&F $366-78$.

${ }^{182}$ Alberstein, ‘Therapeutic Keys of Law’, p 143.

${ }^{183}$ G. Berman and J. Feinblatt, 'Problem-Solving Courts’ p 126.

${ }^{184}$ Ibid. p. 134.
} 
faced originally. Moreover, courts imposing the penalties may have done little to ensure that the social services interventions they mandate are effective. ${ }^{185}$ Singer, writing about the therapeutic orientation of the family courts in the USA, notes that this development 'enhances the role of non-legal professionals', ${ }^{186}$ may detract from the courts' 'fundamental role as a forum for fair ${ }^{187}$ and authoritative dispute resolution’ and may divert services from the wider community. ${ }^{188}$

In England, problem solving courts have been set up to address the same sorts of issues and they use the same sorts of strategies. Unlike courts in the United States, they do not feature clients' 'tearful testimonies', audience applause, graduation ceremonies, ${ }^{189}$ or judges handing out doughnuts. ${ }^{190}$ However, they do use monitoring, they use the coercive power of the court in the form of judicial persuasion and they adopt a therapeutic approach. This is apparent, for example, in at least one specialist domestic violence court ${ }^{191}$ as well as the new Drug and Alcohol court currently being piloted. ${ }^{192}$

${ }^{185}$ Ibid. p. 135.

186 J. Singer, 'Dispute Resolution and the Postdivorce Family: Implications of a Paradigm Shift' (2009) 47 Family Court Review 363, 364.

187 See also Nolan, Legal Accents, p193.

${ }^{188}$ Singer, 'Dispute Resolution and the Postdivorce Family’, p 367.

${ }^{189}$ Nolan, Legal Accents,, p 12.

190 Ibid. p74.

${ }^{191}$ See M. Hester, J. Pearce and N. Westmarland, Early Evaluation of the Integrated Domestic Violence Court, Croydon. Ministry of Justice Research Series 18/8 (London: MOJ. 2008) para 2.6.

192 See A.Hill, 'Pioneering Court Offers Hope to Addict Mothers' The Observer 05.07.09, p 18; FDAC Research Team, Brunel University, The Family Drug and Alcohol Court (FDAC) Interim Report (2009) http://www.brunel.ac.uk/doc/1311/FDACIRAugust2009.pdf (accessed 11/9/09). 
As is apparent from the reported cases and from the findings of Hunt and Macleod, the family courts had begun to adopt similar ways of dealing with parties even prior to the amendment of the Children Act 1989. Already family courts were using adjournments to review and hence monitor contact. Already, judges were seeking to use their authority to persuade mothers to accede to contact despite their fears for their children. Now, under the amended legislation, the powers are more coercive. Courts are empowered to impose treatment regimes or at least counselling or educational retraining on parents and, in the majority of cases, the parents concerned are likely to be mothers resisting contact.

Insofar as they adopt comparable approaches, our family courts will be open to criticisms similar to those levelled at problem-solving courts. The education or counselling on offer, when and if these are made more widely available, ${ }^{193}$ are not necessarily going to be appropriate or effective. Walker et al, for example reported that parents wanted information and advice tailored to their needs and wanted it to take account of changing situations. There was 'little evidence' that the information meetings piloted in terms of the now defunct provisions of the Family Law Act 1996 had a significant effect on behaviour. ${ }^{194}$

\footnotetext{
193 Hunt and Macleod report a degree of scepticism among their interviewees concerning the effectiveness of these measures and the resources available to give effect to them (Hunt \& Macleod, Outcomes, pp 225-226). However the response to the possibility of parenting classes was positive (p 225). Wall LJ has stressed the need for resources ('Making Contact Work in 2009', 591. Some indication of the limited services available is provided by Sayers, 'In Practice: Contact Activities'.

${ }^{194}$ Walker et al, Picking up the Pieces, Executive Summary, Ch 11. However the Resolution information workshops currently being piloted in six areas do appear to met with parental approval (Weekend Woman’s Hour, 4.00pm Saturday 18 July BBC Radio 4).
} 
Even if the services available could be tailored to individual needs, there are serious objections. May and Smart, for example, suggest that the courts are engaging in 'micromanagement' of family life and that they 'do not have the appropriate knowledge and tools to succeed in this goal'. ${ }^{195}$ Other objections stem from the way in which the available knowledge is interpreted and applied; there is a failure on the part of the courts and welfare professionals such as Cafcass officers ${ }^{196}$ to take account of 'the complexities of individuals' problems' and also of the complexities of child welfare knowledge. This failure can lead them to wrongly identify one parent, usually the resident mother, as the problem.

\section{The Main Problem with the Problem-Solving Approach}

The effect of a more problem-solving approach on mothers is as yet unclear. Yet in the light of the prioritization of contact and the continued perception of mothers who oppose it as obstructive, one may speculate that they will be put under increased pressure.

The designation of mothers as the problem means that they are in effect to be dealt with by the family courts in a way that is not entirely different from the way in which problem solving courts deal with violent abusers and drug users. In the same way that, for example, drug users are the focus of the problem-solving measures, so mothers are likely to be the target of intervention to facilitate contact. It is likely to be the mother who is cast firmly as the person who is at fault or the person who needs to change.

${ }^{195}$ V. May and C. Smart, 'The Parenting Contest: Problems of Ongoing Conflict Over Children' in Parenting after Partnering, M. Maclean (ed.) (Oxford: Hart Publishing, 2007) pp78-9.

${ }^{196}$ Cafcass is expected to engage in problem solving. See Parental Separation; Children’s Need and Parents’ Responsibilities (2004 HM Government) para 10. Advice to the court on the necessity and suitability in any case of therapeutic or educational intervention is expected to come from Cafcass officers who are largely pro-contact. See Hunt and Macleod, Outcomes. 
Indeed in the recent case of $\operatorname{Re} P$ (Children), ${ }^{197}$ the Court of Appeal, determined to deal with 'the true underlying issue, 198 in a contact case, was willing to consider recommending counselling for a mother whom the judge in the court below had concluded was truthful and not suffering from any mental disorder. ${ }^{199}$ The therapy, it was said, 'might go some little way to assuaging the father's implacable conviction that she is a woman with severe mental problems such as to spill over to the detriment of his children'. ${ }^{200}$ The father, who had been back to court 66 times, ${ }^{201}$ and who had engaged in what the court considered 'less serious' violence, ${ }^{202}$ was expected to seek help in the form of anger management classes. However the court clearly sympathized with his point of view; he needed an arena in which he could 'explain his feelings of anger and bitterness' resulting from the marriage breakdown and difficulties over the children (who were refusing to see him): ${ }^{203}$ 'It is enough to make any ordinary man just a little bit angry, but that anger has to be contained....hence the need for him to subject himself to what may be the humiliation of counselling and therapy' ${ }^{204}$ That the mother might be distressed at attending therapy that she appeared not to need, was not mentioned.

\footnotetext{
${ }^{197}$ Re P (Children) [2008] EWCA Civ 1431

198 Ibid. [36].

199 Ibid. [24].

200 Ibid. [37]

201 Ibid. [4]

202 Ibid. [5].

${ }^{203}$ One of the children stated that, if his father shouted at him or smacked him, he would curl up and hide his face. He also feared that his father would not return him home after contact (Ibid. [31]).

${ }^{204}$ Ibid. [36]. The court also seemed to sympathize with the fact that a 'proud, intelligent father' had been humiliated by the findings of domestic violence against him.
} 
While it might seem appropriate to subject a violent person or a substance misuser to treatment, education and monitoring, it is questionable whether it is appropriate for recalcitrant mothers. For one thing, these mothers often do have salient reasons for opposing contact. To treat such mothers as being in need of counselling to help them to become reconciled to contact is to pathologize their frequently very real and well-founded worries. And as far as education in the form of parenting classes is concerned, this is likely to be relatively ineffective. It is not lack of knowledge that makes mothers resist contact. Research suggests that mothers tend to accept and tend to have internalized the dominant welfare discourse that prioritizes contact as being best for children. What they do not accept is that contact is good for their children. On the contrary, they see themselves as protecting their children from harm which they believe is likely to result from contact with an abusive or uninvolved former partner; they perceive themselves as fighting for their children's best

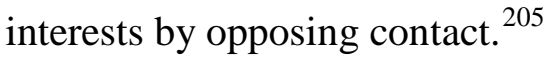

Admittedly, in some cases, as in $R e P$, it will be fathers who will be sent to classes or programmes. However it appears that even then the aim could be to get the mothers to change; some fathers might be sent to anger management or parenting education not only to improve their behaviour but also to allay resident mothers' concerns about violence or poor parenting capacity, so making them more amenable to contact. $^{206}$

\footnotetext{
205 Day Sclater \& Kaganas 'Contact: Mothers, Welfare and Rights’; Kaganas \& S Day Sclater 'Contact Disputes: Narrative Constructions of “Good Parents”' . ${ }^{206}$ See Re P (Children) [2008] EWCA Civ 1431, para 26. The NYAS recommended that the father should attend counselling so that the mother, if he could at least begin to understand the effects of his behaviour, might be reassured and so become more supportive of contact.
} 
Nevertheless it must be conceded that the new measures may lead to the resolution of some disputes. Intervention, whether aimed at fathers or mothers, might lead to greater maternal acceptance of contact. In particular, the new measures may be quite useful in 'persuading' mothers who would otherwise 'get away with' unreasonable behaviour. As one judge in Hunt and Macleod’s study said:

Committal doesn’t work because nobody is prepared to do it. And the real hard core know that. But if there is a lesser punishment. If you're going to have to do community service every weekend it might trigger a few cases. ${ }^{207}$

But the consequences of using these powers could be seriously detrimental to mothers and their children in many cases. Moreover, intervention to get mothers to change their attitudes and their ways by means of these 'lesser' punishments may be followed up with more coercive intervention. ${ }^{208}$

It has been suggested by a Cafcass Acting Head of Service that there are some cases where contact cannot and should not take place and the courts ought not to assume that it should. If an 'educative, therapeutic approach' does not yield results, further applications should be rejected; 'If the situation cannot be changed, the process should stop' ${ }^{209}$ However this advice runs contrary to current thinking. It is more likely that the courts will regard a failure to attend classes or counselling in accordance with an order, or will regard attendance that is not

\footnotetext{
207 Judge quoted by Hunt \& Macleod, Outcomes, p 226.

208 The potential for punitive use of the provisions is noted by Cantwell (B Cantwell 'In Practice: the Emotional Safeguarding of Children in Private Law [2010] Fam Law 84, 89-90; Wall, 'Making Contact Work in 2009'.

${ }^{209}$ S Adams 'Parents’ Rights v Children’s Needs in Private cases’ [2007] Fam Law 257, 258.
} 
followed by change, as evidence of mothers’ unreasonableness justifying further punishment. Resistance to re-education, for instance, may serve as proof that more coercive measures are warranted. That there is some substance to this speculation is demonstrated by the words of another judge quoted by Hunt and Macleod:

I can certainly see the need in some cases to change those attitudes....It will be interesting to see whether the mum in that case would consider attending those classes. And what do you do if she won't? I suppose it gives strength to the arm of enforcement. It reinforces the fact that this is an implacable case. ${ }^{210}$

\section{Conclusion}

The court is considered an unsuitable forum for dealing with contact disputes but it is nevertheless expected to resolve the most intractable cases. The court is also now responsible for ensuring that the parties 'make contact work'. The traditional role of the court as decision-maker has therefore expanded: courts are charged with, and accept the task of, securing the desired outcome: 'good' contact.

For some years mothers who oppose contact or disobey orders have been constructed as the problem. What has changed is the way in which the legislature, and the courts themselves, have decided how to approach this problem. The solution chosen is to enable family courts to act in a way analogous to problem-solving courts. What family courts are 'for', now, includes not only seeking to persuade parents (mainly mothers) to comply but also deciding to refer them to services so that they address their underlying problems. Courts have become part of a

${ }^{210}$ Hunt and Macleod, Outcomes, p 226. 
therapeutic network being deployed to change attitudes and behaviour. Conversely, helping agencies have now become part of the disciplinary framework governing families, and in particular resident mothers. These 'helping' services have in effect been incorporated into the family justice toolkit, backed up by punishment. What is happening here appears to be at least the beginnings of a blurring between adjudication and social work, the very blurring that was warned against in earlier years. What the implications of this might be remain to be seen.

While an approach akin to a 'therapeutic' or 'problem solving' one may not be intrinsically oppressive, in the context of the pro-contact and outcome oriented culture of the family court, it can serve to increase pressure on mothers. It may be that court personnel will be even more easily able to mount hobby horses on the authority of a selective and simplified version of child welfare knowledge.

If mothers, despite real and well-founded misgivings, do not accede to contact, the courts’ new zeal coupled with their new powers increase the possibility that mothers could subjected to unnecessary and unwanted education or counselling. Courts may be far more willing to send mothers for what will be seen as helpful and benign intervention than they might be to impose immediate punitive sanctions. Yet the new powers also make punitive sanctions more likely; if mothers do not respond to 'help’ or ‘education’, their non-co-operation and continued opposition may well be seen as justifying the penalty of community service or even harsher measures

There is a difference between the 'problems' facing, say, domestic violence or drug courts and those facing family courts. There is some consensus that violence and addiction are generally negative in their effects but it is not so clear cut that mothers who oppose contact 
are causing harm. It cannot be assumed that most mothers who are in this position are simply obdurate and are trying to 'get away with' bad behaviour. It cannot be assumed that where measures such as supervised contact are adopted, mothers should be reassured that contact is 'safe', workable or positive. It cannot be assumed that judicial scrutiny of consent orders will bring to light cases of fear, pressure and intimidation. Yet as long as the courts and many of the professionals involved in contact disputes subscribe to the view that contact is almost always in the child's best interests, the legitimate concerns of resident mothers will continue to be sidelined. And as long as the prevailing belief is that courts can make contact 'work', resistance will simply be met with intensified intervention. Many mothers and their children are likely to be worse off as a result. 